\title{
Implementasi Metode Amtsilati Dalam Meningkatkan Kemampuan Maharah Qiro’ah
}

\author{
Ach. Sholehuddin \\ Universitas Nurul Jadid (UNUJA) Paiton Probolinggo \\ udinpaiton123@gmail.com \\ Mu'alim Wijaya \\ Universitas Nurul Jadid (UNUJA) Paiton Probolinggo \\ prabuwidjaya11@gmail.com
}

\begin{abstract}
This study presents the Implementation of the Amtsilati Method in Improving the Ability of Maharah Qiro'ah at the Amtsilati hostel in $\mathrm{K}$ Pondok Pesantren Nurul Jadid, Paiton, Probolinggo area. The purpose of this study was to describe how the Amtsilati method was implemented in improving Maharob Qiro'ah's skills in the Amtsilati K Pondok Pesantren Nurul Jadid area. This research is a descriptive study with a qualitative approach. The subjects in this study include educators, dormitory managers and students. Data collection techniques used were interviews, observation and documentation. The collected data is analyzed through several stages: display data, data reduction and conclusion. And the results of this study indicate that the Application of the Amtsilati Method in the Amtsilati dormitory of K Pondok Pesantren Nurul Jadid Area was able to improve the skill of Maharah Qiro'ah. The application of the Amtsilati method is in line with its application, except that there is little difference with the application of Amtsilati at its center Darul Falah Islamic Boarding School, Jepara. The learning process with the Amtsilati Method in Pesantren Nurul Jadid begins with reading khulashoh, hadloroh, qoidah then explanation, exposure to some examples, synchronization and evaluation
\end{abstract}

Keywords : Amtsilati Method, Maharab Qiro'ah

\begin{abstract}
Abstrak
Penelitian ini menyajikan tentang Implementasi Metode Amtsilati Dalam Meningkatkan Kemampuan Maharah Qiro'ah di asrama Amtsilati wilayah K Pondok Pesantren Nurul Jadid, Paiton, Probolinggo. Tujuan dari penelitian ini adalah untuk mendeskripsikan bagaimana implementasi metode Amtsilati dalam
\end{abstract}


meningkatkan keterampilan Maharoh Qiro'ah di asrama Amtsilati wilayah K Pondok Pesantren Nurul Jadid. Penelitian ini merupakan penelitian deskriptif dengan pendekatan kualitatif. Subyek pada penelitian ini meliputi tenaga pendidik, pengelola asrama dan peserta didik. Teknik pengumpulan data yang digunakan adalah wawancara, observasi dan dokumentasi. Data yang dikumpulkan dianalisis melalui beberapa tahapan: display data, reduksi data dan pengambilan kesimpulan. Dan hasil dari penelitian ini menunjukkan bahwa Penerapan Metode Amtsilati di asrama Amtsilati wilayah K Pondok Pesantren Nurul Jadid mampu meningkatkan keterampilan Maharah Qiro'ah. Penerapan metode Amtsilati sudah sesuai dengan penerapannya, hanya saja ada sedikit perbedaan dengan penerapan Amtsilati di pusatnya Pondok pesantren Darul Falah, Jepara. Proses pembelajaran dengan Metode Amtsilati di Pesantren Nurul Jadid di awali dengan membaca khulashoh, hadloroh, qoidah lalu penjelasan, pemaparan beberapa contoh, sinkronisasi lalu evaluasi.

Kata Kunci : Metode Amtsilati, Maharah Qiro'ah

\section{Pendahuluan}

Dalam dunia pendidikan di Indonesia, lebih-lebih lagi di Lembaga Pendidikan Islam, Pondok Pesantren dan yang lainnya, tidak memandang Bahasa Arab dengan sebelah mata, bahkan hampir seluruh pendidikan di Indonesia sangat memperhatikan akan pentingnya bahasa Arab. Dapat dibuktikan dengan adanya kesejajaran antara mata pelajaran Bahasa Arab dengan mata pelajaran yang lain pada jenjang dan program tertentu. ${ }^{1}$

Dalam bahasa Arab, bila diurutkan sesuai dengan maharah yang mampu menumbuh kembangkan kebahasaan pelajar terdapat terdapat empat mabarah yakni istima' (menyimak), syafany atau kalam (berbicara), qiro'ah (membaca) dan tabriri atau kitabah (menulis) ${ }^{2}$. Apabila lebih dikerucutkan lagi, maka akan menjadi 2 yakni recivetif skill dan produktif skill, recivetif skill terdapat pada mabarah istima' dan qiro'ah. Sedangkan produktif skill terdapat pada maharah kalam dan Kitabah. Keempat mabarah di atas harus saling melengkapi dan menyempurnakan seperti halnya istima' (menyimak), kalam (berbicara) dan kitabah (menulis) sangatlah berkontribusi besar pada dan sangat berharga dalam qiro'ah (membaca), dan begitu pula sebaliknya.

${ }^{1}$ Syarifah Aini dan Mu'allim Wijaya, Metode Mimicry-Memorization (Mim-Mem Method) Dalam Meningkatkan Penguasaan Mufrodat Peserta Didik Di Madrasah, Palapa, Jurnal Studi Keislaman dan Ilmu Pendidikan 6, no. 1 (2018).

2 Rusydi Ahmad Tho'imah "al-Maharat al-Lughowiyab: Mustawayatuba, Tadrisuba, Shu'ubatuba”, (Kairo, Darul Fikri Al aroby: 2004). hlm 37. 
Mabarah Qiro'ah adalah salah satu mabarah yang harus dicapai oleh peserta didik dalam belajar bahasa Arab, karena peserta didik yang tidak bisa membaca akan merasa kesulitan dalam mengikuti pelajaran dan tak terkecuali bahasa Arab. Maharah Qiro'ah bukan hanya sekedar melihat dan memandangi teks bahasa Arab semata, namun juga bagaimana pembaca dapat memahami apa yang dibaca sehingga teks yang dibaca tersebut menjadi teks yang bermakna, tidak hanya menjadi lambang bunyi semata. ${ }^{3}$ Salah satu ilmu yang menjadi penunjang untuk kemampuah qiro'ah adalah gramatikal bahasa Arab itu sendiri, yang biasa dikenal dengan ilmu alat (nabwu dan shorrof). Kedua ilmu ini tidak bisa dipisahkan, Karena keduanya saling berkaitan. Menurut sebagian ulama' sharaf sebagai ibunya dan nabwu sebagai bapaknya. Sharaf yang melahirkan kalimat dan Nahwu yang memperbaiki dari segi susunan juga i'rob-nya. ${ }^{4}$ Sebagai salah satu disiplin ilmu yang sangat berpengaruh dalam bahasa Arab, ilmu alat (nahwu dan shorof) ini sangatlah penting dan tidak bisa diabaikan, sebab tanpa ilmu nahwu bahasa Arab akan menjadi tak beraturan oleh karena itu, dalam mempelajari bahasa Arab, ilmu alat ini sangat penting untuk diketahui.

Kini, terdapat kesan bahwa ilmu alat ini termasuk dari salah satu disiplin ilmu yang susah untuk dimengerti, padahal cukup banyak sudah metode yang dipakai oleh guru dalam mengajarkan ilmu ini, tetapi peserta didik tetaplah merasa kesulitan dalam mempelajarinya. Oleh karena itu, sangatlah perlu seorang pendidik menggukan metode yang tentunya sesuai dengan materi yang akan dijelaskan kepada peserta didik, dari urutan-urutan materi yang harus diajarkan kemudian bagaimana memancing gairah belajar mereka. Sehingga dengan metode itu peserta didik akan lebih mudah dalam memahami ilmu alat ini. $^{5}$

Di Pondok Pesantren Nurul Jadid terdapat asrama yang memang di khususkan untuk santri yang ingin memiliki kemampuan membaca kitab kuning dan metode yang dipakai adalah karya dari seorang mushonnif dari salah satu pondok pesantren di Bangsri, Jepara, Jawa Tengah yang berjudul "Program Pemula Membaca Kitab Kuning Amtsilati”. Metode Amtsilati ini sudah diterapkan selama 9 tahun dan telah mewisuda sebanyak 9 kali angkatan. ${ }^{6}$ Amtsilati adalah metode yang berisikan gramatikal bahasa arab dan merupakan ringkasan dari nadram Alfiyah Ibnu Malik karangan Imam Muhammad bin Abdullah bin Malik

${ }^{3}$ Ibadi Rohman, Arabic Puzzle Book Pengembangan Media Interaktif Untuk Keterampilan Membaca Bagi Siswa Kelas IV MI Di Kota Semarang, Lisanul Arab Journal of Arabic Learning and Teaching 5, no. 1 (2016).

${ }^{4}$ Moh. Anwar, Ilmu Sharaf Terjemahan matan kailani dan Nadzam al-Maqshud berikut penjelasannya, (Bandung: Penerbit Sinar Baru), hlm 5.

${ }^{5}$ Wawancara dengan Ilyas Junaidi Ad dakhil, tanggal 16 Desember 2018 di Kantor wilayah K Pesantren Nurul Jadid, Probolinggo.

${ }^{6}$ Wawancara dengan Syafiqurrosyid, tanggal 10 Desember 2018 di Kantor Amtsilati wilayah K Pondok Pesantren Nurul Jadid, Probolinggo. 
al-Andalusy atau sering dipanggil dengan julukan Imam Ibnu Malik, namun dijelaskan secara ringkas namun padat.

Menurut jenisnya, penelitian ini termasuk penelitian lapangan (field research). Sedangkan, model penelitiannya termasuk pada penelitian deskriptif dengan metode studi kasus yang merupakan bagian dari penelitian kualitatif, artinya informasi dari berbagai narasumber/informan di sajikan dalam bentuk kata-kata dan bahasa pada suatu konteks khusus yang alamiah ${ }^{7}$. Dalam hal ini peneliti ingin menguraikan secara lengkap tentang penerapan metode amtsilati dalam meningkatkan Mabarah Qiro'ab di Wilayah K Pondok Pesantren Nurul Jadid Paiton Probolinggo dengan prosedur pemecahan masalah diantaranya menggambarkan keadaan subjek atau objek penelitian. Dengan metode penelitian ini, peneliti berusaha mengungkapkan dan menganalisis secara detail tentang implementasi metode amtsilati dalam meningkatkan Mabarah Qiro'ah di Wilayah K Pondok Pesantren Nurul Jadid Paiton Probolinggo.

Penelitian ini memposisikan peneliti sebagai instrumen dibantu pedoman observasi, pedoman wawancara, dan dokumentasi. Dari observasi peneliti memperoleh data tentang gambaran utuh kegiatan belajar mengajar di asrama Amtsilati. Kemudian dengan wawancara, peneliti memperoleh hal-hal yang berhubungan dengan metode Amtsilati, bagaimana penerapannya dalam meningkatkan Maharah Qiro'ah. Kemudian dengan dokumentasi, peneliti memperoleh data-data pendukung seperti jadwal kegiatan, struktur kepengurusan, dll.

\section{Hasil dan Pembahasan}

\section{A. Pengertian Amtsilati}

Amtsilati merupakan suatu trobosan metode baru yang disusun oleh $\mathrm{KH}$. Taufiqul Hakim seorang kyai yang karismatik dan pendiri Pondok Pesantren Darul Falah Bangsri, Jepara, yang diharapkan mampu membantu para pelajar untuk menemukan kemudahan dalam mempelajari ilmu-ilmu yang berkaitan dengan bahasa Arab terlebih dalam Maharah Qiro'ah. Berawal dari terdengarnya metode cepat membaca al-Qur'an yaitu dengan adanya kitab Qiro'ati beliau terdorong untuk mengupas pada harokat bacaannya. Kata أمثئت adalah bentuk jamak dari lafadz مثال yang bermakna contoh-contoh dan berakhiran " $t i{ }^{\prime \prime}$ yang bermakna saya, jadi kata أمثلتي secara etimologi bermakna contoh-contoh saya.

Amtsilati merupakan metode yang sangat praktis dan dapat membantu para pemula untuk lebih mudah dalam memahami ilmu nabwu dan shorrof.

\footnotetext{
${ }^{7}$ Lexy Moleong, Metode Penelitian Kualitatif, (Bandung: PT Remaja Rosdakarya, 2010), hlm. 62 .

${ }^{8}$ Taufiqul Hakim, Amtsilati Program Pemula Membaca Kitab Kuning. Jepara : offset, 2004. hlm. 8 .
} 
Sehingga beberapa orang yang awalnya menganggap mempelajari ilmu nabwu dan shorof sangatlah sulit menjadi mudah."

Jika dapat didefenisikan, maka Amtsilati adalah :

$$
\begin{aligned}
& \text { قواعد اللغة العربيسة الأساسية على الطريقة الحديثة بأمثلة من الأيات القرأنية سهولة } \\
& \text { الهضم والفهم المحبوبة واللائقة للمبتدئين من الصبيان والغلمان ذوي الهرم الهيد }
\end{aligned}
$$

"Qoidab-qoidab Bahasa Arab tingkat dasar dengan model terbaru, dengan contob-contoh dari ayat-ayat Al-qur'an yang mudah dicerna, mudah difahami dan menyenangkan, layak bagi pemula baik kanak-kanak, remaja ataupun kawak-kawak.".

Kitab Amtsilati merupakan metode sekaligus tersusun dalam bentuk kitab yang berisikan beberapa materi ilmu alat yang terprogram dengan penulisan yang sistematis bagi para pemula dalam belajar membaca kalimat berbahasa arab dalam kurun waktu 3-6 bulan. Kitab tersebut berisikan tentang qowa'id (nabwu dan shorrof). Kitab tersebut disusun mengingat akan pentingnya belajar ilmu Qowa'id (nahwu dan shorrof) serta mempermudah para pemula yang ingin mempelajari ilmu tersebut.

Jadi, Amtsilati merupakan sebuah alat atau cara yang disajikan guru dalam bentuk kitab Amtsilati, dimana kitab tersebut lebih mentitik tekankan kepada lebih memperbanyak contoh dan praktek dengan tujuan murid dapat membaca naskah-naskah berbahasa arab dengan baik. Amtsilati membahas tentang gramatikal bahasa Arab dan metode cepat tepat untuk para pemula, dan hanya membutuhkan waktu kurang lebih 6 bulan untuk memahaminya.

\section{B. Metode Pembelajaran}

Dikarenakan tantangan zaman yang kian menjadi momok bagi pemuda untuk mempelajari ilmu agama khususnya kitab-kitab klasik atau biasa disebut kitab kuning. Amtsilati merupakan kabar gembira bagi mereka yang memiliki keinginan kuat akan hal tersebut. Amtsilati merupakan ringkasan dari nadzam Alfiyah Ibnu Malik karangan Imam Muhammad bin Abdullah bin Malik Al andalusy dan yang sangat unik dari Amtsilati adalah bait nadzam Alfiyah Ibnu Malik yang asalnya berjumlah 1002 bait diringkas dengan seringkas-ringkasnya oleh Mushonnif-nya menjadi 184 bait nadzam saja.

${ }^{9}$ Azzah Nor Laila dan Fathu Rohman, "Pesantren Amtsilati Sebagai Rolde Model Pendidikan Berbasis Anti Radikalisme Di Jepara," Al-Fikri Jurnal Studi Dan Penelitian Pendidikan Islam 1, no. 2 (2018).

${ }^{10}$ Baihaki, "Kilas Karakteristik Amtsilati," 2017.hlm 2. 
Adapun beberapa metode pembelajaran yang dilaksanakan yaitu :

\section{Klasikal}

Salah satu model pembelajaran yang diterapkan di Amtsilati adalah model klasikal dengan cara membentuk beberapa kelompok belajar yang pesertanya sesuai dengan tingkatan jilidnya masing-masing.

\section{Konsep Belajar Tuntas}

Belajar tuntas Belajar tuntas termasuk salah satu sistem pembelajaran yang dapat diimplementasikan di dalam suatu kelompok belajar. Konsep belajar tuntas merupakan system pembelajaran yang bertujuan agar tujuan pembelajaran dapat dikuasai oleh peserta didik secara tuntas. Agar peserta didik mendapatkan hasil seperti apa yang diharapkan, metode Amtsilati menerapkan konsep belajar tuntas yang terlaksana dalam segi :

a. Tujuan

Amtsilati merupakan metode cepat yang tentunya tujuan dari pembelajarannya adalah bagaimana peserta didik bisa menguasai dalam waktu sesingkat-singkatnya tentunya dengan prosedural yang sudah ada pada Amtsilati. Amtsilati mentargetkan peserta didik bisa menguasai dalam kurun waktu kurang lebih 6 bulan.

b. Materi

Ada 5 jilid yang harus dikuasai untuk dikatakan selesai belajar Amtsilati, yang masing-masing jilid mempunyai kriteria ketuntasan sendiri-sendiri. Amtsilati jilid 1 memembahas lima bab, yakni : Huruf Jar, Isim Dlomir, Isim Isyaroh dan Isim Maushul Jilid 2 terdiri dari lima bab, yakni : Tanda-tanda Isim/kata benda, Macam-macam Isim/kata benda, Bentuk-bentuk Isim fa'il, Bentuk-bentuk Isim Maful dan Bentuk-bentuk Mashdar. Sedangkan pada jilid 3 terdiri dari enam bab, yakni : Mubtada', Al 'awamil Al nawasikh (kata mempengaruhi Mubtada), Isim Ghoiru Munshorif (isim yang tidak bisa menerima tanwin), Isim Al musytaq (isimisim yang dibentuk dari kata lain), Isim yang berakhiran buruf 'illat dan Tawabi' yang empat yaitu : na'at / sifat, tankid / penguat, 'Athaf / kata sambung dan Badal / pengganti). Pada jilid 4 terdiri dari empat bab, yakni : Fi'il Madli (kata kerja lampau), Fa'il (pelaku), Bentuk-bentuk Fi'il Madli yang mendapatkan tambahan huruf dan Maf'ul bih, maf'ul fih, maf'ul muthlaq, maf'ul li ajlih, bal dan tamyiz (Pelengkap). Dan terakhir pada jilid 5 terdiri dari enam bab, yakni : Fi'il Mudhari' (kata kerja yang bermakna sekarang atau akan datang), Bentuk-bentuk Fi'il Mudhari' yang mendapatkan tambahan huruf, Kata yang menashabkan Fi'il Mudhari', Kata yang menjazemkan Fi'il Mudhari', Fi'il Amr (kata perintah) dan yang terakhir Mubimmaat (kaidah-kaidah penting).

Selain jilid 1 sampai 5 di atas, Amtsilati juga dilengkapi dengan 1 kitab Qo'idati (berisikan rumus dan kaidah-kaidah dari jilid 1 sampai jilid 5) yang 
disusun agar peserta didik lebih mudah dalam kembali muthola'ah apa yang telah dipelajari, Sharfiyah (metode praktis memahami Shorof dan I'lal) yang bertujuan untuk mengetahui proses perubahan kalimat secara Istilabi dan Lughowi, Khulashoh (berisikan ringkasan Nadham Alfiyah Ibnu Malik disertai makna pegon, bahasa Jawa dan bahasa Indonesia) dan yang terakhir Tatimmah (perumusan/penerapan rumus Amtsilati).

c. Evaluasi

Untuk mengetahui tercapai atau tidaknya hasil pembelajaran, dilaksanakan dua metode tes, yaitu yang pertama adalah tes lisan. Tes lisan adalah jenis tes yang mana peserta harus berhadapan langsung dengan penguji dan langsung menjawab pertanyaan dari penguji, soal tes meliputi kaidah, materi dan pemberian contoh. Setelah tes lisan dirasa sudah cukup mumpuni dan di anggap lulus, kemudian di lanjut dengan tes kedua yakni, tes tulis. Tes tulis dilaksanakan seusai tes lisan, para peserta diharuskan tes secara tulis sesuai dengan beberapa soal yang sudah disusun oleh para Asatids:

Dari uraian-uraian di atas tentang Amtsilati di atas, menunjukkan bahwa metode ini lebih memberikan banyak kesempatan kepada setiap peserta didik untuk lebih aktif. Dan membiasakan peserta didik untuk mengulang materi akan membuat mereka semakin merasa mudah dalam memperlajari ilmu ini.

\section{Pengertian Maharah Qiro'ah}

Umar Shiddiq mendefinisikan keterampilan membaca sebagai berikut: "Pemaknaan kata-kata tertulis atau pemaknaan terhadap teks, dengan kata lain penulis mentransformasikan pemikiran-pemikirannya terhadap pembaca, sedangkan pembaca menterjemahkan pemikiran-pemikiran tersebut berdasarkan pengalaman dan latar belakangnya, baik secara budaya maupun kebahasaan". ${ }^{11}$

Keterampilan membaca (Maharah Qiro'ab) mengandung dua pengertian. Yang pertama, kemampuan mengubah lambang tulisan menjadi lambang bunyi. Kedua, memahami seluruh makna yang tertuang dalam lambang tulisan maupun dalam lambang bunyi. ${ }^{12}$

Keterampilan membaca (Maharah Qiro'ab) adalah suatu keterampilan berbahasa yang dimiliki oleh seseorang dalam melihat, memahami serta

${ }^{11}$ Umar Shiddiq Abdullah dan Mahmud Ismail shini "al Mu'inaat al Bashoriyah fi al Lughah al Arobiyah (jami'ah al malik al su'ud, 1984) hlm. 105.

${ }^{12}$ Sri Sudiarti, "Peningkatan Keterampilan Membaca Teks Arab Gundul Melalui Aktifitas Membaca Intensif Berbasis Gramatikal: Studi Kasus Mahasiswa Bahasa Dan Sastra Arab IAIN STS Jambi," Fenomena 7, no. 1 (2015). 
memaknai apa isi yang terkandung dalam sebuah tulisan dengan terampil dan fasih. $^{13}$

Membaca merupakan pengetahuan dan pikiran. Ini adalah cara pertama yang bisa digunakan untuk lebih memperluas persepsi, mengembangkan suatu informasi serta cara untuk memperoleh budaya. Membaca merupakan kegiatan yang dapat menumbuhkan kreativitas serta inovasi, bahkan merupakan landasan dalam kemajuan bangsa. ${ }^{14}$

Jadi, pada hakikatnya keterampilan membaca adalah seni komunikasi dua arah antara pembaca dan penulis. Dalam konteks pembelajaran bahasa Arab (keterampilan membaca) pembaca mampu melafalkan bacaannya secara jelas dan fasih serta mampu menterjemahkan bahkan mengembangkan maksud penulis dengan baik dan benar.

\section{Tujuan Membaca}

Secara khusus tujuan keterampilan membaca (marbalah qiro'ah) terbagi sesuai dengan tiga tingkatan, tingkatan dasar (ibtidaiyah), menengah (mutawassithoh) dan tingkat tinggi (mutaqoddimab) ${ }^{15}$ serta tujuan dari setiap tingkatan juga berbeda. Tujuan keterampilan membaca tingkat dasar (ibtidaiyah) yaitu Memahami kode-kode bahasa, memahami kata dan kalimat, mengungkap pokok pikiran dan juga bertujuan untuk mengungkapkan kandungan-kandungan bacaan (re-telling). Sedangkan tujuan keterampilan membaca tingkat menengah (mutawassithoh) adalah Mengungkapkan ide pokok serta ide pendukung dan mengungkapkan kandungan-kandungan bacaan yang beraneka ragam (re-telling). Dan yang terakhir tujuan keterampilan membaca tingkat tinggi (mutaqoddimah) antara lain adalah mengungkapkan ide pokok serta ide pendukung dan menafsirkan kandungan-kandungan bacaan.

Sementara menurut Yayan Nurbayan membaca memiliki beberapa tujuan. Tujuan yang akan mempengaruhi karakteristik membaca yang akan dibaca, yaitu ${ }^{16}$ :

1. Meneliti, membaca kadang bertujuan sebagai prasyarat dalam penelitiannya.

Maka seorang peneliti mencari banyak refrensi yang sesuai dengan objek yang akan ia teliti.

13 Anwar Abd. Rahman“Keterampilan Membaca Dan Teknik Pengembangannya Dalam Pembelajaran”, Jurnal Diwan,3 no. 2 (2017).

${ }^{14}$ Rahadian Kurniawan, "Mahara Al-Qiro'ah Fi Al-Madrasah Al-Tsanawiyah Al-Hukumiyah Air Bangis Pasaman Al-Gharbiyah (Dirasab Tabliliyah 'An Tadrisiba Wa Shu'ubatiba)" Arabiyatuna, 2, no. 1 (2018).

15 Ali Ahmad Madkur, "Tadris Funun al Lughah al Arobiyab”, (Kuwait, Maktabah al Falah, 1984), hlm 109.

16Yayan Nurbayan, Metodologi Pembelajaran Bahasa Arab, 2008.hlm 102. 
2. Meresume, membaca terkadang juga memiliki tujuan untuk meringkas suatu teks dengan mengambil uraian-uraian yang kiranya penting dan membuang uraian-uraian yang dianggap tidak penting.

3. Memberitahu, seorang pembaca teks kadang-kadang bertujuan untuk memberitahu atau mengumpulkan apa yang ada di dalam teks yang dibacanya, seperti yang dilakukan oleh penyair radio atau televisi.

4. Ujian, sebelum melaksanakan ujian, seorang pasti akan membaca teks yang akan diujikan dengan sangat hati-hati agar tidak ada kesalah pahaman dan dengan berulang-ulang untuk mendapatkan sebuah pemahaman

5. Kesenangan, orang yang memiliki hobi membaca biasa mengisi waktu luangnya dengan membaca dan saat itu pula mereka merasa senang ketimbang melakukan hal-hal yang tak berfaedah.

6. Beribadah, seorang membaca terkadang bertujuan untuk mendekatkan diri kepada Allah, seperti membaca Al qur'an.

Dari ulasan di atas dapat disimpulkan bahwa tujuan membaca sesuai dengan tingkatan masing-masing namun pada intinya adalah mampu mengungkapkan ide pokok pada teks bacaan, menguraikannya bahkan menafsirkannya dengan jelas dan gamblang.

\section{E. Macam-macam Qiro'ah}

Apabila dilihat dari segi penyampaiannya, qiro'ab terbagi menjadi dua bagian, yaitu :

\section{a. Qiro'ah Jahriyah}

Membaca secara nyaring (qiro'ah jahriyah) adalah cara membaca yang lebih menitik tekankan kepada aktifitas anggota bicara, mulai dari bibir ataupun tenggorokan untuk mengeluarkan bunyi. Hal yang paling nampak dalam jenis ini adalah kata "jahriyab" (nyaring), yakni pembaca membaca teks dengan fasih, makhrojnya tepat, harokatnya jelas serta secara tidak langsung pembaca langsung mencerna apa yang telah dia baca. ${ }^{17}$

Secara umum, setiap jenis maharah qiro'ah memiliki keunggulan yang berbeda. Sedangkan keunggulan dari qiro'ah jahriyah antara lain adalah melatih kefasihan dan kemampuan membaca peserta didik, melatih kelancaran peserta didik dalam menjabarkan makna serta pemikirannya, melatih mempraktekkan kaidah-kaidah bahasa arab, makhorijul buruf dan yang terakhir qiro'ah jabriyah merupakan salah satu wasilah untuk membantu menumbuh kembangkan peserta didik yang minder.

${ }^{17}$ Jaudaat al Rukkabi, Thuruq al Tadris al Lughah al Arobiyah, (Bairut, Darul Fikr, 1997), hlm. 86 . 


\section{b. Qiro'ah As shomitah}

Menurut Sholeh Santo membaca dalam hati (qiro'ah al-shomitah) adalah kemampuan sensorik secara sadar tanpa dilafadzkan. ${ }^{18}$ Sedangkan menurut Sami Mahmud Abdullah qiro'ah al-shomitah (membaca dalam hati) adalah memahami teks bacaan dan memberikan arti yang cocok sesuai dengan kemampuan pembaca dari segi pengalaman dan latar belakangnya tanpa pengucapan. ${ }^{19}$

Sedangkan jenis yang kedua ialah qiro'ah al-shomitah (membaca dalam hati) yang merupakan kebalikan dari qiro'ah jahriyah, yakni Cara membaca yang hanya diam memaknai setiap lambang bunyi yang ada dengan tanpa adanya aktivitas organ berbicara.

Sedangkan bila dilihat dari segi bentuknya, mabarah qiro'ah terbagi menjadi dua macam $^{20}$ :

\section{a. Qiro'ah Mukatsafah (membaca intensif)}

Adapun ciri dari jenis ini adalah memiliki tujuan untuk memperkaya kosa kata dan penguasan peserta didik terhadap kaidah-kaidah yang sesuai dengan kebutuhan dan proses pembelajaran diawasi oleh pendidik untuk mengetahui sejauh mana perkembangan peserta didik.

b. Qiro'ah Muwassa'ah (membaca ekstensif atau membaca cepat)

Adapun ciri dari jenis ini adalah memliki tujuan untuk meningkatan pemahaman terhadap teks yang dibaca dan sebelum kegiatan dilaksanakan, pendidik memberi arahan serta menentukan teks bacaan serta mendiskusikannya.

\section{F. Implementasi Metode Amtsilati dalam Meningkatkan Kemampuan Maharah Qiro'ah di Pesantren Nurul Jadid}

Amtsilati yang terdapat di Wilayah K Pondok Pesantren Nurul Jadid sendiri merupakan cabang dari Amtsilati Pondok Pesantren Darul Falah, Jepara, yang merupakan kediaman mushonnif Amtsilati. Akan tetapi pada Amtsilati di Pesantren Nurul Jadid terdapat beberapa kelebihan dan memiliki keunikan tersendiri. Terdapat beberapa inovasi yang baru dari para pengurus, misalnya praktek tanya jawab antara Asatidz dan peserta didik yang dilakukan rutin setelah

18 Muhammad Sholeh Santo, " al Maharaat al Lughawiyah Mudakhon ila Khoshoishi al Lughah al Arobiyah wa Fununuba", (Diwanu al Madinah, Daru al Andalus, 1994). hlm. 176.

${ }^{19}$ Sami Mahmud Abdullah, "Ba'du al 'uyub al Sya'iah fi al Qiroah al Shomitah baina al Talamidz al Shoffi al Robi' al Ibtidai, Thesis (tidak dicetak), fakultas tarbiyah, Universitas Al Azhar, 1975. no. 1 (2013).

${ }^{20}$ Sri dahlia, "Urgensi Metode Qiroab Dalam Pembelajaran Bahasa Arab Di PTAI," Arabia 5, 
sholat isya', untuk menambah daya rangsang dan kepekaan peserta didik terhadap kalimat-kalimat berbahasa arab. ${ }^{21}$

Adapun langkah-langkah pembelajaran Amtsilati secara konseptual adalah sebagai berikut ${ }^{22}$ :

1. Membaca Hadloroh untuk penyusun dan yang mensyi'arkan metode Amtsilati

2. Ustadr, membacakan bab yang akan dipelajari, lalu membacakan contohcontoh yang ada tanda ( saja.

3. Peserta didik membaca bersama-sama contoh ayat $2 \mathrm{x}$, bacaan pertama sesuai sesuai Qoidah Nahwiyah, bacaan kedua dibaca sesuai dengan Qoidah Tajwid.

4. Peserta didik mengulang keterangan yang di bawahnya dan membaca dasar baitnya yang sudah ada pada Khulashoh.

5. Membaca contoh ayat sesuai dengan urutan turun ke bawah.

6. Kemudian latihan memberi makna

7. Pada akhir pertemuan, membaca ulang qoidah materi yang sudah dibahas.

8. Dan pada pertemuan selanjutnya, jangan lupa mengulang materi yang sudah dipelajari.

Pembelajaran Amtsilati di Pondok Pesantren Darul Falah dilaksanakan pada jam 08.00 - 11.00, lalu di lanjutkan 13.00 - 15.00 dan jam 20.00 - 21.00. Namun, di asrama Amtsilati wilayah K Pondok Pesantren Nurul Jadid waktu pembelajarannya sesuai observasi peneliti hanya dilaksanakan dua kali, yakni Ba'da Subub sampai waktu sholat dbuba dan jam 20.00 - 21.00 WIB, dan para Asatid r. mencoba sedikit menghias langkah-langkah pembelajaran yang sudah ada dan menyeimbangkan sesuai keadaan yang ada. Dalam satu pertemuan, ustadz membahas satu atau beberapa materi yang berkesinambungan. Misalkan pada jilid 3 pada pembahasan Mubtada' dan Khobar.

1. Sebelum pembelajaran dimulai, peserta didik membaca Kbulashoh jilid 3, dan diawali dengan Hadloroh kepada Mushonnif, orang tua, guru dan yang menyebar luaskan metode Amtsilati.

2. Dengan petunjuk ustadz peserta didik membaca Qoidah Mubtada' dan Khobar.

3. Ustadz sedikit menjelaskan tentang Qoidah yang dibaca.

4. Ustadz memberi contoh Mubtada' dan Khobar.

5. Ustadz mensingkronkan contoh Mubtada' dan Khobar dengan materi sebelumnya. Misalnya :

\footnotetext{
${ }^{21}$ Hasil wawancara dengan Amaluddin, Pembina Amtsilati, tanggal 29 Desember, tahun 2018 di Kantor Sekretariat Amtsilati.

${ }^{22}$ M. Misbah, "Taufiqul Hakim 'Amtsilati' Dan Pengajaran Nabwu-Sharaf," Pemikiran Alternatif Kependidikan 11, no. 3 (2006).
} 


\begin{tabular}{|c|c|c|}
\hline \multicolumn{3}{|c|}{ البستان جميل } \\
\hline Lafadz & Ustadz & Peserta Didik \\
\hline \multirow{5}{*}{ البستان } & - Rumus Utamanya apa ?kenapa? & $\begin{array}{l}\text { Isim, karena ada tanda isim } \\
\text { vaitu } \mathrm{Al}\end{array}$ \\
\hline & - Rumus A1nya apa? & $\begin{array}{l}\text { Ma'rifat, Mu'rob, Mudqakkar } \\
\text { dan Mufrod }\end{array}$ \\
\hline & $\begin{array}{l}\text { - Kedudukannya menjadi apa ? } \\
\text { kenapa? }\end{array}$ & $\begin{array}{l}\text { Mubtada, karena isimma'rifat } \\
\text { di awal kalimat }\end{array}$ \\
\hline & - Mubtada' hukumnya apa? & Rofa' \\
\hline & $\begin{array}{l}\text { - Pada lafadz tersebut tanda } \\
\text { rofa'nya apa? kenapa? }\end{array}$ & $\begin{array}{l}\text { Tanda rofa'nya dlommah, } \\
\text { karena isim I }\end{array}$ \\
\hline \multirow{5}{*}{ 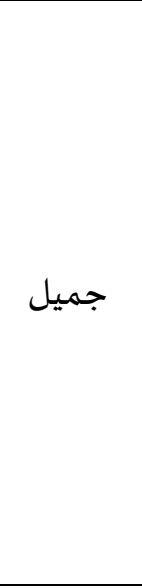 } & - Setelah mubtada' ada apa? & Khobar \\
\hline & - Bagaimana ciri-ciri khobar? & $\begin{array}{l}\text { Terletak setelah mubtada' dan } \\
\text { pantas diberi makna ialah }\end{array}$ \\
\hline & - Khobar hukumya apa? & Rofa' \\
\hline & $\begin{array}{l}\text { - Apa yang menyebabkan khobar } \\
\text { dibaca rofa'? }\end{array}$ & Sebab adanya mubtada' \\
\hline & - Dasarnya & 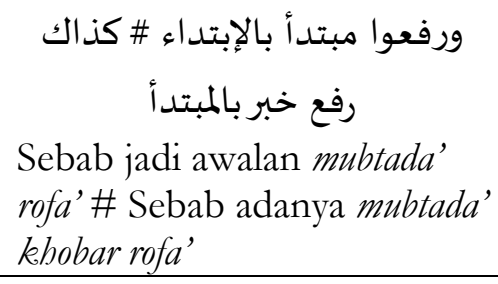 \\
\hline البستان & - Dibaca sesuai makna & $\begin{array}{l}\text { ج = Adapun Kebun } \\
\text { = Indah }\end{array}$ \\
\hline
\end{tabular}

6. Memberi contoh yang semisal di atas, lalu pertanyaannya mengarah kepada satu persatu peserta didik. Jadi peserta didik ditanya satu-satu sesuai dengan pembahasan yang ada.

7. Ustad₹ memberi tugas untuk dikerjakan di asrama dan akan dibahas pada awal pertemuan selanjutnya.

Peserta didik diharuskan menghafal Qoidah dan Kbulasob yang sudah tertulis dalam kitab Amtsilati guna lebih mempermudah santri dalam menangkap materi yang disampaikan asatidz serta peserta didik harus menyetorkannya kepada para asatidz yang sudah siap menerima setoran dan biasanya Standby di depan kamar santri setiap Ba'da Ashar.

Hal ini dikuatkan oleh hasil wawancara dengan Ahmad Baidlowi selaku Pengajar Amtsilati: 
Semua santri di haruskan menghafal rumus Qaidah dan Khulasoh yang sudah tersusun rapi di kitab Amtsilati untuk mempermudah santru dalam memahami Amtsilati, babkan alangkah lebih baiknya jikalau hafalan santri melebibi materi yang akan dibahas. Sehingga, sebelum asatidz, menjelaskan materi yang akan dibahas, para santri sudab mumpunyai sedikit gambaran tentang materi tersebut dan menanyakan hal-bal yang di anggap musykil bagi santri. ${ }^{23}$

Terkait dengan beberapa hal yang harus di hafalkan oleh peserta didik diatas, diperkuat lagi oleh pernyataan kepala Amtsilati, Yazid Ringgit :

Termasuk ciri khas dari Amtsilati adalah teori sebelum materi, ini juga merupakan sebuah perbedaan Amtsilati dibanding dengan metode klasik yang lain, jadi sebelum memasuki materi atau pembahasan, santri harus hafal Qoidah dan Khulasoh materi tersebut. Sehingga, mereka tidak terkejut ketika mulai masuk materi dikarenakasn belum mempunyai gambaran tentang meteri yang akam dibahas. Sedangkan, jika santri sudah hafal, maka sedikit banyak. mereka sudah mempunyai gambaran tentang materi itu.

Dalam kegiatan belajar mengajar nampak terlihat bagaimana santri saling bersaing untuk menjadi yang lebih cepat tuntas serta memahami Amtsilati. Sebagaimana disampaikan oleh Yazid Ringgit selaku kepala Amtsilati dalam wawancaranya :

Amtsilati merupakan metode cepat untuk bisa membaca kitab kuning, yang terkadang bisa menghabiskan beberapa tahun, namun Amtsilati sendiri mentergetkan 6 bulan. Maka dari sebab itu, pembelajaran Amtsilati memakai jenis KBM (kegiatan belajar mengajar) berbeda dengan metode yang berjalan di berbagai instansi secara umum, seperti sorogan ataupun wetonan. ${ }^{24}$

Peserta didik yang mempelajari Amtsilati di wilayah $\mathrm{K}$ ini mayoritas bahkan hampir keseluruhan belum pernah mempelajari bahasa arab maupun ilmu alat (nabwu dan shorrof), yang mana keduanya merupakan salah satu penunjang yang sangat inti dalam Maharah Qiro'ah. Jadi, dapat disimpulkan bahwa peserta didik di asrama Amtsilati benar-benar berangkat dari ketidaktahuan. Kemudian seiring dengan kemampuan mereka dalam menempuh setiap jilidnya, terdapat beberapa peningkatan yang mereka capai sesuai dengan target yang telah ditetapkan pada setiap jilidnya.

Pada jilid satu dan dua peserta didik mulai dapat mengetahui mengelompokkan serta membedakan kata benda (isim) beserta macammacamnya. Seperti membedakan kata benda yang laki-laki (mudzakekar) dan yang

\footnotetext{
${ }^{23}$ Hasil wawancara dengan Ahmad Baidlowi, Pengajar Amtsilati, tanggal 02 Januaari, tahun 2019 di Kantor Sekretariat Amtsilati.

${ }^{24}$ Hasil wawancara dengan Yazid Ringgit, Kepala Amtsilati, tanggal 29 Desember, tahun 2018 di Kantor Sekretariat Amtsilati.
} 
perempuan (muannats), membedakan sesuai dengan jumlah isim (mufrod, mutsanna dan jamak).

Pada jilid tiga peserta didik dapat menyusun kalimat serta menentukannya dalam qiro'ah, namun hanya sebatas kalimat nominal (jumlah ismiyah) saja.

Dan saat di jilid empat dan lima peserta didik mulai mengenal kata kerja (fi'i) mulai dapat menentukan dan menentukan kalimat verbal (jumlah fi'liyah) serta sudah mampu menyatu padukan apa yang telah dipelajari mulai dari jilid satu sampai jilid lima hingga mulai dapat membaca teks qiro'ah dengan benar.

Semakin tinggi jilid yang ditempuh oleh peserta didik, maka lebih tinggi pula tingkat kesulitan kalimat yang diberikan oleh para asatidz kepada peserta didik. Misalkan pada jilid tambahan, dikarenakan para peserta didik sudah tuntas menempuh jilid 1 sampai jilid 5, maka selain diberikan kalimat untuk mereka terjemah sesuai dengan kaidah Amtsilati, ustadz tenaga pengajar jilid tambahan juga menggunakan sistem sorogan kitab Safinatun Najah. Sebagai latihan mereka dalam memaknai kitab kuning.

Disamping kegiatan-kegiatan yang sudah ada, terdapat beberapa kegiatan penunjang yang merupakan inovasi dari pengurus asrama Amtsilati untuk menunjang peningkatan peserta didik dalah maharah qiro'ah, di antara lain :

\section{Tamrin}

Setiap selesai sholat isya' terdapat kegiatan untuk meningkatkan kemampuan maharah qiro'ah peserta didik yang biasa disebut dengan tamrin, yakni seluruh Asatidz setiap malam bergantian memberikan kalimat berbahasa arab didepan semua peserta dari jilid 1 sampai jilid tambahan dan membahasnya dengan menanyakan per kalimat kepada peserta yang jilidnya sudah sampai pada pembahasan itu. Seperti yang disampaikan oleh Ahmad Baidlowi :

Para asatidz. mulai membiasakan santri membiasakan santri membaca teks berbahasa arab sejak jilid satu. dimulai dengan kalimat-kalimat pendek sampai yang panjang. Babkan nanti ketika jilid terakbir atau biasa kita sebut jilid tambaban, mereka akan menghafalkan kitab Safinatun Najah. Dan juga setiap ba'da sholat isya' para asatidz. bergantian memberikan kalimat berbahas arab. Dan di ikuti semua jilid, dari jilid 1 sampai jilid tambahan. ${ }^{25}$

2. Belajar Privat

Para asatid₹ di asrama Amtsilati juga memberi keleluasaan kepada peserta yang ingin belajar prifat. Yakni menggunakan waktu di luar kegiatan dengan semaksimal mungkin untuk menambah pematerian mereka. Para peserta didik yang rajin sangat memanfaatkan momentum ini, sebab belajar prifat dapat

\footnotetext{
${ }^{25}$ Hasil wawancara Ahmad Baidlowi.
} 
membantu mereka memperoleh pemahaman dan mempercepat mereka naik ke jilid selanjutnya.

3. Motivasi

Dalam proses pembelajaran, para Asatidz tak lupa menyelingi proses pembelajaran dengan memberikan motivasi kepada para santri. Memotivasi santri dianggap sangatlah penting, karena mengingat semangat peserta didik yang kadang kala naik turun. Hal ini sesuai dengan pernyataan Yazid Ringgit:

Para asatidz, sering kali menyela-nyela pelajaran dengan memotivasi santri, agar terus semangat dan memiliki keinginan yang kuat untuk mencapai tujuan yang dituju. Karena terkadang sebagian santri hanya mempelajari kaidahnya semata dengan tanpa adanya praktek dalam qiro'ah. Sebingga Asatidz dianggap perlu untuk selalu memompa semangat santri demi tercapainya tujuan yang di barapkan. $^{26}$

\section{Penutup}

Berdasarkan pemaparan dari hasil penelitian tentang Implementasi Metode Amtsilati dalam Meningkatkan Kemampuan Maharah Qiro'ah, maka penulis dapat menyimpulkan bahwa implementasi Metode Amtsilati asrama Amtsilati wilayah K Pondok Pesantren Nurul Jadid mampu Meningkatkan Kemampuan Maharah Qiro'ah, dibuktikan dengan adanya peserta didik yang awal memulainya benar-benar berangkat dari nol setelah menyelesaikan Amtsilati mereka mulai dapat membaca teks berbahasa arab terlebih pada kitab kuning. Adapun proses pembelajaran yang diterapkan dimulai dengan membaca Khulasoh bersama, membaca hadloroh lalu membaca rumus qoidah dilanjutkan dengan penjelasan disertai dengan beberapa contoh kemudian mensinkronkan dengan materi sebelumnya disertai dengan memberikan contoh dan menanyakan kepada satu - persatu peserta didik dan pada akhir pertemuan memberikan tugas kepada peserta didik.

Penerapan Metode Amtsilati dalam Meningkatkan Kemampuan Maharah Qiro'ah di asrama Amtsilati Wilayah K Pondok Pesantren Nurul Jadid, Paiton, Probolinggo, sesuai dengan penerapannya. Namun untuk lebih meningkatkan kemampuan santri dalam Maharah Qiro'ah, terdapat beberapa kegiatan penunjang yang diharapkan mampu membantu dalam meningkatkan kemampuan Maharah Qiro'ah namun tidak keluar dari koridor Amtsilati, seperti tamrin, belajar prifat dan motivasi dari para asatidz.

Implementasi metode Amtsilati ini sangat membantu kepada orangorang yang ingin mempelajari bahasa arab khususnya dalam Maharah Qiro'ah karena metode Amtsilati merupakan sebuah metode yang sudah menyatu dengan kurikulumnya. Didalamnya sudah tertata rapi beberapa Qoidah yang

${ }^{26}$ Hasil Wawancara Yazid Ringgit 
ringkas namun padat. Namun disamping semua kelebihan yang ada, juga terdapat beberapa kendala dalam Implementasi Metode Amtsilati dalam meningkatkan Maharah Qiro'ah di Wilayah K Pondok Pesantren Nurul Jadid antara lain yang pertama kendala dari guru yakni, terdapat asatidz yang sangat kurang kreatif dalam memenejemen suasana pembelajaran yang lebih menarik, sehingga terdapat sebagian peserta didik yang semangat dalam belajar naik turun. Dan kendala yang kedua dari peserta didik yang berupa minimnya peserta didik dalam penguasaan kosa kata bahasa arab dan kaidah-kaidah bahasa arab (nahwu dan shorrof).

\section{Bibliografi}

al-Rukkabi, Jaudat, Thuruq al Tadris al Lughah al Arobiyah, (Bairut, Darul Fikr, 1997

Azzah Nor Laila dan Fathu Rohman, Pesantren Amtsilati Sebagai Rolde Model Pendidikan Berbasis Anti Radikalisme Di Jepara, Al-Fikri Jurnal Studi Dan Penelitian Pendidikan Islam 1, no. 2 (2018).

Anwar Abd. Rahman"Keterampilan Membaca Dan Teknik Pengembangannya Dalam Pembelajaran", Jurnal Diwan,3 no. 2 (2017).

Baihaki, Kilas Karakteristik. Amtsilati, 2017.

Ibadi Rohman, Arabic Puzৃle Book Pengembangan Media Interaktif Untuk Keterampilan Membaca Bagi Siswa Kelas IV MI Di Kota Semarang," Lisanul Arab Journal of Arabic Learning and Teaching 5, no. 1 (2016).

M. Misbah, "Taufiqul Hakim 'Amtsilati' Dan Pengajaran Nahwu-Sharaf," Pemikiran Alternatif Kependidikan 11, no. 3 (2006).

Madkur, Ali Ahmad, "Tadris Funun al Lughah al Arobiyah", Kuwait, Maktabah al Falah, 1984

Muhammad Sholeh Santo, " al Maharaat al Lughawiyah Mudakhon ila Khoshoishi al Lughah al Arobiyah wa Fununuha”, (Diwanu al Madinah, Daru al Andalus, 1994). Hal. 176.

Moh. Anwar, Ilmu Sharaf Terjemahan matan kailani dan Nadzam Al maqshud berikut penjelasannya, Bandung: Penerbit Sinar Baru, t.th.

Rahadian Kurniawan, "Mahara Al-Qiro'ah Fi Al-Madrasah Al-Tsanawiyah AlHukumiyah Air Bangis Pasaman Al-Gharbiyah (Dirasah Tabliliyah 'An Tadrisiba Wa Shu'ubatiha)" Arabiyatuna, vol. 2, no. 1 (2018).

Rusydi Ahmad Tho'imah, al-Maharat al-Lughowi: Mustawayatuba, Tadrisuba, Shu'ubatuha", (Kairo, Darul Fikri Al aroby: 2004). 
Taufiqul Hakim, Amtsilati Program Pemula Membaca Kitab Kuning. Jepara : offset, 2004.

Umar Shiddiq Abdullah dan Mahmud Ismail shini, al-Mu'inaat al-Bashoriyah fi alLughah al-Arobiyah, Makkah: Jami'ah al-Malik al-Su’ud, 1984.

Sri Sudiarti, Peningkatan Keterampilan Membaca Teks Arab Gundul Melalui Aktifitas Membaca Intensif Berbasis Gramatikal: Studi Kasus Mahasiswa Bahasa Dan Sastra Arab LAIN STS Jambi, Fenomena 7, no. 1 (2015).

Syarifah Aini dan Mu'allim Wijaya, Metode Mimicry-Memorization (Mim-Mem Method ) Dalam Meningkatkan Penguasaan Mufrodat Peserta Didik Di Madrasah, Palapa, Jurnal Studi Keislaman Dan Ilmu Pendidikan 6, no. 1 (2018).

Yayan Nurbayan, Metodologi Pembelajaran Bahasa Arab, 2008.

Sami Mahmud Abdullah, Ba'du al-'Uyub al-Sya'iah Fi al-Qiroah al-Shomitah Baina alTalamidz, al-Shoffi al-Robi' al-Ibtidai, Thesis (tidak dicetak), Fakultas Tarbiyah, Universitas al-Azhar, 1975.

Sri dahlia, "Urgensi Metode Qiroah Dalam Pembelajaran Bahasa Arab Di PTAI," Arabia 5, no. 1 (2013). 
64 | Arabiyatuna : Jurnal Bahasa Arab, Vol. 3, No. 1, 2019

HALAMAN INI SENGAJA DIKOSONGKAN 